\title{
The Critical Review on the Adoption of ICTs in the Small and Medium Enterprises (SMEs) in the Developing Countries
}

\author{
Nasser Saif Al Busaidi \\ $\mathrm{PhD}$ Fellow \\ Faculty of Business and Accountancy \\ University of Selangor, Malaysia \\ E-mail:albu500@hotmail.com \\ Abul Bashar Bhuiyan PhD \\ Associate Professor \\ Faculty of Business and Accountancy \\ University of Selangor, Malaysia \\ E-mail:bashariuk@gmail.com \\ Norhayah Zulkifli $P h D$ \\ Professor \& Dean \\ Faculty of Business and Accountancy \\ University of Selangor, Malaysia \\ E-mail:norhayah@unisel.edu.my
}

\begin{abstract}
The Small and Medium Enterprises (SMEs) are considered as the mainstay of the economy, whereas the Information and Communication Technologies (ICTs) is regarded as unitary of the major drivers for SMEs. The function of the ICT is to ensure that as far as the organizations are concerned, their strategy and design, innovation of new products, services, processes, productivity, expansion of market size, improvement of product qualities, enhancement of performance and, development, as well as supporting business competitiveness can be executed accordingly. However, debates about the efficient uses of ICTs by SMEs in developing nations are being discussed and reported widely. Therefore, this study analyzes the critical success factors on the ICTs adoption in the SMEs globally focusing on Oman. Questionnaire survey is conducted among the managers of the SMEs. It is found that the effective adoption of ICTs in the SMEs is caused by a number of success factors including among others limited access to markets and, finance, lack of awareness to global markets, unfriendly business environment, poor management skills and lack of updated technology. complication of the bureaucracy process, as well as lack of training relating to basic business.
\end{abstract}

Keywords: ICTs Adoption, Critical Success Factors on the ICTs Adoption \& SMEs.

\section{Introduction}

It has been widely recognized that the adoption and use of information and communication technologies (ICTs) becomes an essential element of organization's strategy and represents a fundamental source of facilitating innovation and enchaining performance, growth, and competitiveness for firms that are able to exploit them (Ashrafi \& Murtaza, 2008; Bayo-Moriones, Billón, \& Lera-López, 20I3; Díaz-Chao, Sainz-González, \& Torrent-Sellens, 20I5; Higón, 20I2). At the same time, the Small and Medium Enterprises (SMEs) are considered as vital engine for the economic growth in every nation. Empirical evidence has been provided in literature to explain the positive influence of the SMEs sector on the economic, industrial and social development of the countries nationwide. In most countries, SMEs generate a substantial percentage of GDP, a central component of the country's economic stability, and a primary source of business creation and poverty relief, income generation and distribution as well as training ground for entrepreneurship and new venture ideas (Ashrafi \& Murtaza, 2008; Chugtai \& Alam, 2014; Ongori \& Migiro, 2010). Moreover, SMEs account for 99.7\% of jobs in the United States and over 95\% globally, in that $90 \%$ of them include matter pertaining to computer organization as function of their everyday operations. In developing countries, SMEs also contribute to poverty alleviation, create business opportunities, enhance entrepreneurial skills among the endowments, and function as a source of development for the state and its rural regions (Okundaye, 2016). 
In the same way the ICTs adoption and uses by the firms had become an important topic of academic research during recent decades. There has been an increasing number of theoretical and empirical studies that have demonstrated the importance to gain and exploit the positive outcomes of ICT adoption and uses on the organization capabilities and consequently on its performance, growth, and competitiveness (Tarutè \& Gatautis, 20I4). However, the context of these studies was mainly focused on large organizations. Studies that explore and examine the contributions of ICTs adoption among SMEs and its effect on firm's capabilities, such as marketing capabilities, and consequently its effect on business performance, growth, and competitiveness is limited. Lack of empirical research in SMEs context is one of the factors that contribute practically to the low rate of ICTs adoption among SMEs and therefore the potential of ICTs adoption is not fully exploited. Other factors including, for instance, limited financial and technological resources, infrastructure and organizational capabilities also led to the low adoption rate of ICT (Consoli, 2012).

Globally It is also found that the diffusion of ICT in SMEs compared to large companies is still low in most countries (Al-Qirim, 2004; Consoli, 2012). In developing countries, the situation of ICT adoption in SMEs is not encouraging due to many obstacles and challenges that the companies face such as limited financial, technology, and human resources/capabilities, although the less complicated structure allows them to have better flexibility to changes. Thus, the present study has taken timely initiative to address the current status of adoption and uses of ICTs of the SMEs in developing countries specifically Oman.

\section{The Concept and Development of ICTs}

The ICTs refers to any technology that enables communication and the electronic capturing, processing and transmission of information (Ashrafi \& Murtaza, 2008). These technologies include products and services such as desktop computers, laptops, handled devices, wired or wireless intranet, business productivity software such as editor and spreadsheet, enterprise software, data storage and network security among others (Ashrafi \& Murtaza, 2008). In addition, ICTs is described as a collection of hardware, software, and services within an enterprise used to process information in order achieve the organization's goal and objectives (Okundaye, 2016). Moreover, Wangwe (2007) described ICT as myriad of stand-alone media, such as telephone and mobile phone, radio, television, video, tele-text, voice information systems and fax, as well as computer, linked or even not linked, to the Internet. He described ICT as an integrated system that incorporates the technology and infrastructure required to store, manipulate, deliver and transmit information. Furthermore, (Ongori \& Migiro, 20I0) state that ICTs include a collection of software, hardware, telecommunication and information management technologies, applications and devices that are used to create, produce, analyze, process, package, distribute, retrieve, store and transform information. Hence, ICT can be referred to as an organized communication networks and data resource that collect, transform and spread information within and among enterprises including SMEs(Apulu, Latham, \& Moreton, 20I I).

According to (Campo, Rubio, \& Yagüe, 2010), the development of information and communication technologies, in the last two decades, has created important changes in organizations. These changes can be noticed in their organizational structures, processes, relationships with other firms, and have assisted them to enhance and improve their economic performance and relational performance. Similarly, (Selamat, Jaffar, \& Kadir, 2013) state that effectively using ICT by SMEs, can provide good opportunity to take advantage in enhancing their competitive advantage, establishing a global and international network of product exchange, and improving their business process. Earlier in 2006, Kollberg \& Dreyer stated that many organizations used ICT in a wide range of business activities and operation areas, providing new ways to store, process, distribute and exchange information within the organizations as well as with their Stakeholders (Kollberg \& Dreyer, 2006). Nowadays, organizations also use ICTs to run their inventories, control accounting, manage and develop their human resources, etc. Moreover, ICTs can be used as critical tool to improve the quality of products and services, reduce storage cost, accelerate processes and eliminate or reduce paperwork, and communicate effectively with stakeholders and partners. In order that organization, including SMEs, utilize ICTs effectively, all managers and staff should be well trained to acquire technology skill in order to be able to search and gather data from different sources, analyze them, select the relevant ones and organize them in such a manner as to allow them make a suitable and proper decisions based on the information (Eze, Ayigbe, Eberechi, \& Jordan, 2015). Also, the policymakers should develop accurate policies to promote effectively the diffusion of ICT, and managers should take actions, within their organizations, to motivate ICT usage and improve performance by adapting indicators such as the ability to attract more customers, to produce innovative production, and to participate in overseas markets (Higón, 20I2).

\section{The Process of ICTs Adoption in SMEs}

The ICTs have two main wings comprising information and communication technology. Information technology ranges from basic hardware and software such as personal computer equipped with basic hardware and installed with free open source software connected to printer to more advanced and information technology, e.g. PC with updated and sophisticated hardware and software such as databases, Enterprise Resource Planning, Inventory Management, and Customer Relationship Management. In the same sense, communication technology is divided into two groups. First, basic communication includes for example radio, 
landline/mobile phone, and fax. Second, advanced communication capabilities involved for example email, internet browsing, video conferencing, intranet, file sharing, creating websites, e-commerce, and others. The following figure I describes about the progression of ICT Adoption by firms including SMEs.

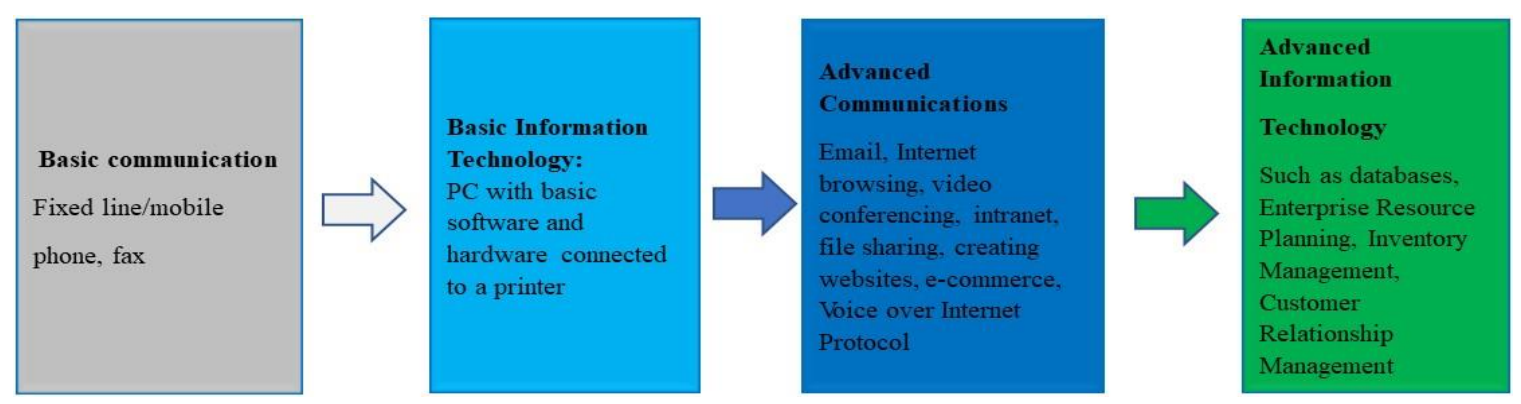

Figure I. Progression of ICT Adoption by firms including SMEs. Source: (Hak-Su, 2007)

The most common information and communication technology (ICTs) by SMEs are, mobile phones, PCs, PCs with local network connected (intranet), email and electronic data interchange, Internet and an own website. The decision of SMEs' owners/managers to choose the type of ICT products depends on many factors such as the actual benefits they can bring to their core business, employees' ICT capabilities, firm's financial resources capacity, and etc. (Hak-Su, 2007). However, usually SME in startup stage can use basic information and communication technologies as most people are familiar with them, including for example, fixed or mobile phone and fax machine, PC with document processing software like Microsoft Words, PowerPoint, etc., and printer. Then within the development of their business activities, they can shift to a more upgrade or advanced communication technology which are actually more complex and slightly expensive compared to the basic one that rely primarily on internet and intranet (Hak-Su, 2007).

Through intranet, employees can share files, memos, and other internal firm's issues with each other and within employees and managers over the same network. Availability of internet connection enables firm to utilize and adopt other ICT tools, such as communication through email, internet searching and browsing, website creation, and conducting of e-commerce. As such this level of ICT adoption provides effective and efficient communication with customers, suppliers, and other firms' stakeholders. Information technology (IT), including products such as Enterprise Resource Planning (ERP), Customer Relationship Management (CRM), Knowledge Management (KM), and Supply Chain Management (SCM), is often very expensive, complex, and need a period of time to be implemented by organizations. SMEs may apply one or more of these technologies if they have the capacity (human and financial resources) to adapt, or they may go for outsourcing option to reduce the costs.

\section{Potential Benefits of ICTs Adoption in SMEs}

In the contemporary and globalized business world, the literatures provide many empirical and theoretical evidence on the benefits that organizations could be benefited if they start to adopt ICT in their strategies and business activities. According to (Ongori \& Migiro, 20I0), ICTs enhance competition, improve knowledge management, access to robust business information, improve administration process, efficient and effective enterprise resource management, control and accountability, broaden market reach in which allow them to expand their sales and growth locally and globally.

Through the use of ICT infrastructure, SMEs are able to engage in e-commerce. This step will allow them in improving the efficiency of their daily business operations and develop their business growth by expanding or entering new market channels. Also, ICTs' adoption in SMEs can reduce significantly the operational costs, such as, decreasing usage of material, procurement and transaction costs, in which it will lead to lowering prices for the final goods and improve the value of their output (Pilat, 2005). SMEs are likely to derive the benefits of ICT adoption through participation in regional and international markets. For instance, in the Caribbean, numerous SMEs have grown and expanded their market globally through extensive use of ICTs which improve customer service and access of information access (Ongori \& Migiro, 20I0). Also, in Jamaica, the adoption of ICTs in the SMEs sector is on the rise, due to increased awareness and decreasing global costs of technologies such as hardware and software (Ongori \& Migiro, 2010). In Singapore and Ireland, ICTs' adoption has affected significantly the growth of SMEs businesses which led to improved SMEs responsiveness to customers/client needs, and compete effectively in both regionally and globally (Al-Jaghoub \& Westrup, 2003). The significant perceived benefits of ICTs include the establishment of reputation in the global markets, enhancing sales, increasing revenues and profit margin, improving 
distribution channels, and competitiveness (Zaidan, 2017). Thus, ICT can be used as a "strategic lever" to reinforce the business strategy of SMEs and to improve competitive advantages in the rapidly globalized and deregulated market (Al-Jaghoub \& Westrup, 2003; Ongori \& Migiro, 2010).

\section{Types of ICTs in SMEs}

ICTs have been categorized into three different groups namely; general-use ICTs, communication-integrating ICTs and marketoriented ICT (Bayo-Moriones et al., 20I3). General-use ICT includes internet access, computer, and other basic ICTs such fax, printers, fixed phone, mobile phone etc. While Communication-integrating ICTs includes e-mail, intranet and extranet, marketoriented ICTs includes e-commerce, web pages and social media applications. This study focuses mainly on the second and third group as they are most commonly use in SMEs operation business and their role and impact in enhancing marketing capabilities and business performance of this type of enterprises. From those two groups of ICTs, the study adopts e mail, e commerce, and social media as independent variables.

Electronic mailing also known as e-mail has become an important method of business communication that is fast, cheap, accessible and easily replicated. Email can greatly benefit businesses as it provides efficient and effective ways to transmit all kinds of electronic data. In addition to text, e-mail messages also contain pictures, videos and sounds, and can be personalized for certain customer groups (Kotler \& Armstrong, 2008; Yusuf, 2013). E-mail has changed the world and has had a tremendous effect on business. It is used to communicate internally with other employees and externally with customers. The invention of email and its early use in communication dates back to the early 1960s when messages could only be sent to users of the same computer. In 1970s, when computers started to work on networks, the current e-mail began that use@ symbol to specify addresses of the email recipients. Companies started to use email in their businesses communication after the military and educational systems. It was easily adopted because of its simplicity, speed and extreme low cost. It was perfect for businesses that had international branches and became a cost-effective way of scheduling information, verifying shipments and confirming transactions. Therefore, the email is almost 40 times more effective than combined Facebook and Twitter in assisting business in attaining new customers. Email is an important ICTs tool for SMEs as it has many advantages such as enhancing products and services marketing, building strong relationship with clients, improving internal and external communication, and attract new and potential customers.

Social media has become an integral part of our daily life for communicating and sharing information and other media, with year-on-year growth in the number of users. At end of November 2018, there are 3.03 billion active social media users worldwide. Facebook has 2.072 billion users, LinkedIn has 562 million users, Twitter has 326 million users, WhatsApp has 900 million users, and YouTube has 1.5 billion users, 8I\% of all SMEs in the world use some kind of social media platform (Brandwatch, 2018). The literature has provided a number of definitions of social media, this is because the term of social media is understood and used in a different way by different people and researchers. However, this study adopts the definition of Kaplan \& Haenlein (2010), in which they define social media as a group of Internet-based applications that build on the ideological and technological foundations of Web 2.0, and that allow the creation and exchange of User Generated Content. According to Ahmad et al. (2018), this is one of the simplest and comprehensive social media definitions.

For enterprises, that their businesses are already internet connected, social media provides broad opportunities to conduct businesses with relatively quick and less cost method of connecting with customers (McCann \& Barlow, 20I5). It has been claimed to transform and affect consumer behavior with more important for firms, products and brands (Kaplan $\&$ Haenlein, 2010). It has been acknowledged by many researchers that social media has brought revolutionary new ways of involving users to interact, participate, cooperate, collaborate, generate content, and connect with other users through new communication approach, that is many-to-many, rather than the traditional one-to-many (Ahmad, Abu Bakar, \& Ahmad, 20I8; McCann \& Barlow, 2015). Social media can even be more beneficial to SMEs because such firms have limited financial and technical resources to market their products or services (Jones, Borgman, \& Ulusoy, 2015). According to (Hassan, Shiratuddin, $\&$ Ab Salam, 20I5) the perceived impact of social media (SM) on business should not be underestimated as literature shows that digitalization in its various forms, including social media, has a positive impact on SME's growth, performance and competitiveness. SMEs can benefit from digital marketing and social media in attracting new target customers and reaching existing ones in easy manner with less cost, as well as facilitating both internal and external communication (Ahmad et al., 20I8; Jones et al., 2015; Kaplan \& Haenlein, 2010; Stockdale, Ahmed, \& Scheepers, 2012; Taiminen \& Karjaluoto, 20I5). Hence, it is important that SMEs should deploy and utilize digital channels, such as social media, if they want to remain competitive and grow (Taiminen \& Karjaluoto, 2015). However, deploying effectively social media in business, SMEs should have a clear plan of how it will be used and what it will be used for (McCann \& Barlow, 20I5).

The previous literatures provide a variety of e commerce definitions because researchers have used the term EC according to the scope of their research. (Kurnia et al., 2015a). Generally, there are two types of electronic business (e commerce) comprising business to consumer ( B2C), and business to business ( B2B) (Yu, Wang, Zhong, \& Huang, 2016). B2C model refers to business that online transactions occur between a business firm and its consumers. Amazon.com, Priceline.com, 
and Souq.com are successful examples of B2C leaders. This type of electronic business requires intensive advertisements to gain and attract customers, high investments in updated hardware and software, and developing a superior customer relationship management (CRM) capability (Nica, 2015). B2B model refers to a situation where one business makes a commercial transaction with another. The volume of B2B transaction is much higher than the volume of B2C (Yu et al., 20I6). However, the purchase of $\mathrm{B} 2 \mathrm{~B}$ products could be riskier than $\mathrm{B} 2 \mathrm{C}$ products due to wrong quantity or wrong terms/ conditions (Sila, 2013). The benefits of internet, such as low cost, speed, and wide accessibility provide good opportunity for electronic commerce (e-commerce) to be increasingly diffused globally, bringing countries together into a global networked economy. The development of online business has changed the traditional way of doing business among organizations, including SMEs. Most businesses worldwide give special attention to the adoption of e commerce by SMEs such as issuing policies and regulations to support them to adapt and use ICT. Despite these efforts by the governments, the adoption of e-commerce by SMEs is still far behind the adoption of ecommerce by large companies. Since SMEs play a vital role in the economic development of a country, it is important to identify the factors behind the low usage of ICT among the companies. They also represent as an incubator for job seekers and recognized as a key driver of economic growth and innovation. Moreover, they contribute to household income and welfare, self-confidence, social change, and political stability (Rahayu \& Day, 20I5).

\section{Issues and Challenges of ICTs Adoption in SMEs}

Unlike in developed and advanced economic countries, the SMEs sector in developing countries have been slow in the adoption of ICTs and a delay or failure in adopting e-transformation technologies (Bunker \& MacGregor, 2000; Manochehri, Al-Esmail, \& Ashrafi, 2012; Ongori \& Migiro, 2010; Ramayah, Ling, Taghizadeh, \& Rahman, 2016). SMEs in developing countries face several challenges and barriers that make them difficult to be adopted. These challenges include, for instance, high cost of access to telecommunications, insufficient government policy towards ICT, lack of skilled and trained workforces, and poor communication infrastructure as well as high cost of internet connectivity, cost of ICT equipment and resistance to change. (Ongori \& Migiro, 2010). The author emphasized, particularly, that one of the strongest factors that hinder SMEs to implement ICTs is lack of information system knowledge, as most owners/mangers and staff do not have the necessary technological knowledge end becomes difficult for them to adopt ICT in their business. In addition, other researchers' report that lack of technical and human infrastructure, political and economic structure, and conservative bureaucratic approach are among other barriers affecting organizations in adopting ICTs effectively (Manochehri et al., 2012). (Kapurubandara, 2008) classified the factors that have been identified as causes for the reticence into external and internal factors. He emphasized that SMEs need support to overcome the barriers, some could be provided internally and some with the help of external interventions or both.

Similarly, in Arab Countries the implementation and adoption of ICTs is facing major challenges due to many factors that hinder or slow down the adoption (Hamade,2009). He categorized these factors into two categories: Firstly, it is related to the basic infrastructure and economic problems, and secondly it is related to government's policies and regulations. In GCC countries, the large and international organizations spent a lot of money on ICT and have effective computer systems to conduct business efficiently. However, the adoption of ICTs in SMEs sector is not the same, partially due to that SMEs do not have sufficient financial and skilled human resources to acquire, maintain and utilize sophisticated ICTs (Ashrafi \& Murtaza, 20I0). For instance, a study conducted by (Manochehri et al., 20I2) to analyze the ICT adoption by SMEs in Qatar, found that there is a need for more training facilities and governments supports in order to enhance the adoption of ICT in SMEs.

\section{Influencing Factors of ICTs Adoption in SMEs}

Unlike large firms, the less complicated structures of SMEs allow them to be more flexible to act and change including the adoption of ICT. However, still the diffusion and potential of ICT in this sector is low and not fully exploited like large companies due to constraints and challenges that they face such as limited resources, technology and ICTs capabilities (Consoli, 20I2). Other researchers identified additional constrains such as poor telecommunications infrastructure, limited ICT literacy, inability to integrate ICT into business processes, high costs of ICT equipment, incomplete government regulations for ecommerce, and poor understanding of the dynamics of the knowledge economy (Hak-Su, 2007). Other reason might be due to that SMEs desire to gain a quick returns and benefits from their investment on ICT tools. However, gaining the advantages and benefits of ICT can only occur after a period of adoption and it depends on the type of business, internal changes such as reengineering process, personnel retraining, and suppliers-customers interaction (Consoli, 20I2). While internal factors include top management, resources, end users, IT solution (computer application), and organizational characteristics, external factors include an external and competitive pressure, customers and supplier, external IT consultant and vendors, as well as government.

Others review prior studies that analyse the factors influencing the adoption of ICT in SMEs and classified them into three groups; factors related to the staff of the company who are going to use ICT, factors related to the characteristics of the company, and factors related to the environment in which the company operates (Ollo-López \& Aramendía-Muneta, 20I2). With regards to the adoption of ICT in SMEs, the factors are classified into five groups (Consoli, 20I2; Skoko, Buerki, \& 
Ceric, 2007) individual, organizational, environmental, technological, and economical factors as described in the figure 2 , below;

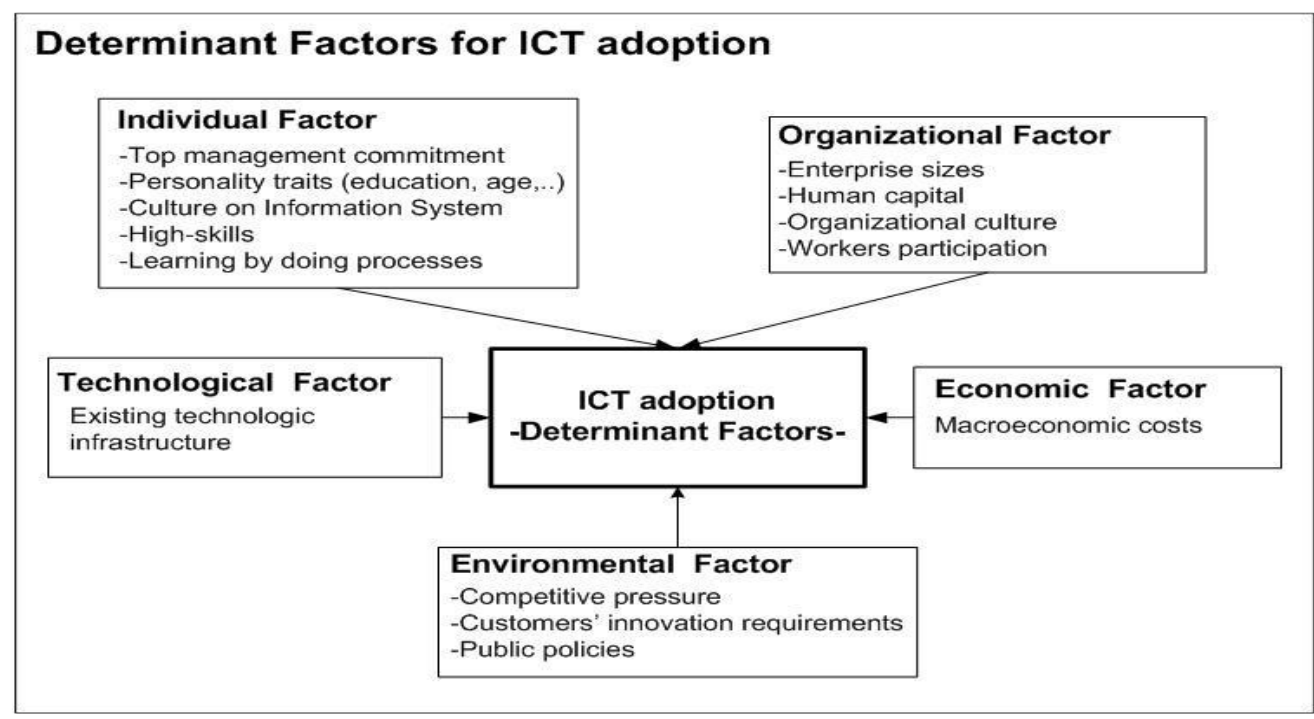

Figure 2. Determinant factors for ICT adoption. Source: (Consoli, 2012; Skoko et al., 2007)

Pertaining to the area of research in developing countries such as Bangladesh, it is found that the awareness of ICT benefits, government and top management support, as well as financial support are the most determinant factors that influence the adoption of ICT among SMEs. In Nigeria, (Apulu \& Ige, 20II) investigate the reasons for non-effectively utilizing of ICT by SMEs using a survey of I80 SMEs. The results revealed that most of SMEs use basic ICT such as word processing, fixed landlines, printers and fax machines. It has been found that using ICT for advance functions such as business analysis, planning and decision making, is very limited.

In Malaysia, (Alam \& Noor, 2009) found that perceived benefits, ICT knowledge, and government support are significantly important to the adoption of ICT while perceived cost and external pressure are found to be insignificant in determining ICT adoption. In addition, Selamat et al. (2013) found three dominant factors that influence the use of ICT in Malaysian SMEs namely, perceived usefulness, perceived ease of use and perceived complexity, while factors such as perceived thrust and management support were not related to ICT usage. In the context of Oman, few studies in the specific area have been conducted but on the whole the research is still very limited (see (Ashrafi \& Murtaza, 2008; Ashrafi \& Murtaza, 20I0; Ashrafi, Sharma, Al-Badi, \& Al-Gharbi, 20I4). For instance, (Ashrafi et al., 20I4) identified, through an empirical research, key factors that are vital for attaining business value by SMEs through ICT adoption. Seven factors were found that assess business value of ICT adoption in SMEs namely: organization and management practices, strategic, informational, transactional and organizational change benefits, impetus for ICT investment and support from government. They also conclude that size of an organization plays the most important role in its ICT infrastructure.

\section{Conclusion and Recommendation}

The present study analyses that there are several studies that have identified the ICTs adoption by SMEs and facilitate to improve their performance and achieve growth by becoming more efficient, effective, innovative, and competitive in national and international markets. The present study identifies the empirical literatures to analyze the critical success factors on the ICTs adoption in SMEs globally and there is an implication that ICT could facilitate businesses to be more efficient, innovative, and competitive. Most studies have been conducted in developed countries and in large organizations, and insufficient empirical research on the uses and adoption of ICTs in SMEs especially in developing countries have been established. It is revealed that a number of factors influence adoption of ICTS in the SMEs including among others lack of strategic vision, unfriendly business environment, poor management skills and lack of updated technology, e-commerce technologies, complicated bureaucracy processes, and difficulties of skill manpower for hiring. The findings will be used as key references for further study on the effective adoption of the ICTs in the SMEs in the context of Oman and the Gulf regions. 


\section{References}

Ahmad, S. Z., Abu Bakar, A. R., \& Ahmad, N. (2018). Social media adoption and its impact on firm performance: the case of the UAE. International Journal of Entrepreneurial Behavior \& Research.

Al-Jaghoub, S., \& Westrup, C. (2003). Jordan and ICT-led development: towards a competition state? Information Technology \& People, I6(I), 93-IIO.

Al-Qirim, N. A. (2004). Electronic commerce in small to medium-sized enterprises: Frameworks, issues, and implications: Igi Global.

Alam, S. S., \& Noor, M. K. M. (2009). ICT adoption in small and medium enterprises: An empirical evidence of service sectors in Malaysia. International Journal of Business and Management, 4(2), II2.

Apulu, I., \& Ige, E. O. (20I I). Are Nigeria SMEs Effectively Utilizing ICT? International Journal of Business and Management, 6(6), 207.

Apulu, I., Latham, A., \& Moreton, R. (20II). Factors affecting the effective utilisation and adoption of sophisticated ICT solutions: Case studies of SMEs in Lagos, Nigeria. Journal of Systems and Information Technology, I3(2), I25-I43.

Ashrafi, R., \& Murtaza, M. (2008). Use and impact of ICT on SMEs in Oman. Electronic Journal of Information Systems Evaluation, $I I(3)$.

Ashrafi, R., \& Murtaza, M. (2010). ICT adoption in SME in an Arab GCC Country Oman. E-strategies for resource management systems: Planning and implementation, 37 I-376.

Ashrafi, R., Sharma, S. K., Al-Badi, A. H., \& Al-Gharbi, K. (2014). Achieving business success through information and communication technologies adoption by small and medium enterprises in Oman. Middle-East Journal of Scientific Research, 22(I), I38-I46.

Bayo-Moriones, A., Billón, M., \& Lera-López, F. (2013). Perceived performance effects of ICT in manufacturing SMEs. Industrial Management \& Data Systems, II3(I), II7-I35.

Brandwatch. (2018). I2I Amazing Social Media Statistics and Facts. Retrieved from https://www.brandwatch.com/blog/amazing-social-media-statistics-and-facts/

Bunker, D., \& MacGregor, R. (2000). Successful generation of information technology (IT) requirements for small/medium enterprises (SME's)-cases from regional Australia. Paper presented at the Proceedings of SMEs in a Global Economy.

Campo, S., Rubio, N., \& Yagüe, M. J. (2010). Information technology use and firm's perceived performance in supply chain management. Journal of Business-to-Business Marketing, I7(4), 336-364.

Consoli, D. (2012). Literature analysis on determinant factors and the impact of ICT in SMEs. Procedia-social and behavioral sciences, 62, 93-97.

Díaz-Chao, Á., Sainz-González, J., \& Torrent-Sellens, J. (20I5). ICT, innovation, and firm productivity: New evidence from small local firms. Journal of Business Research, 68(7), I439-I444. doi:http://dx.doi.org/I0.1016/j.jbusres.2015.01.030

Eze, N. M., Ayigbe, S. F., Eberechi, O. O., \& Jordan, N. (2015). Information and communication technology applications in small and medium scale enterprises (Smes) funding in Nigeria: An impact assessment. International Journal of Finance and Accounting, 4(5), 293-303.

Hak-Su, K. (2007). Small and medium enterprises and ICT.

Hassan, S., Shiratuddin, N., \& Ab Salam, S. N. (2015). Social media as persuasive technology for business in Malaysia. International Journal of E-Business Research (IJEBR), II(2), I8-39.

Higón, D. A. (2012). The impact of ICT on innovation activities: Evidence for UK SMEs. International Small Business Journal, 30(6), 684-699.

Jones, N., Borgman, R., \& Ulusoy, E. (2015). Impact of social media on small businesses. Journal of small business and enterprise development, $22(4), 6 \mathrm{II}-632$.

Kaplan, A. M., \& Haenlein, M. (2010). Users of the world, unite! The challenges and opportunities of Social Media. Business horizons, 53(I), 59-68.

Kapurubandara, M. (2008). A model to eTransform SMEs in Developing Countries. Paper presented at the Information and Automation for Sustainability, 2008. ICIAFS 2008. 4th International Conference on.

Kollberg, M., \& Dreyer, H. (2006). Exploring the impact of ICT on integration in supply chain control: a research model. Paper presented at the Proceedings of the 2006 EurOMA Conference in Strathclyde, Scotland.

Kotler, P., \& Armstrong, G. (2008). Principles of marketing. 12. painos. New Jersey, Person Education Inc.

Manochehri, N. N., Al-Esmail, R. A., \& Ashrafi, R. (2012). Examining the impact of information and communication technologies (ICT) on enterprise practices: A preliminary perspective from Qatar. The Electronic Journal of Information Systems in Developing Countries, 5I(I), I-I6.

McCann, M., \& Barlow, A. (20I5). Use and measurement of social media for SMEs. Journal of small business and enterprise development, 22(2), 273-287. 
Nica, E. (2015). Environmentally sustainable transport and e-commerce logistics. Economics, Management And Financial Markets, IO(I), 86.

Ollo-López, A., \& Aramendía-Muneta, M. E. (20I2). ICT impact on competitiveness, innovation and environment. Telematics and Informatics, 29(2), 204-2I0.

Ongori, H., \& Migiro, S. O. (2010). Information and communication technologies adoption in SMEs: literature review. Journal of Chinese Entrepreneurship, 2(I), 93-I04.

Pilat, D. (2005). The ICT productivity paradox. OECD economic studies, 2004(I), 37-65.

Rahayu, R., \& Day, J. (2015). Determinant factors of e-commerce adoption by SMEs in developing country: evidence from Indonesia. Procedia-social and behavioral sciences, I95, I42-I50.

Ramayah, T., Ling, N. S., Taghizadeh, S. K., \& Rahman, S. A. (2016). Factors influencing SMEs website continuance intention in Malaysia. Telematics and Informatics, 33(I), I50-I64.

Selamat, Z., Jaffar, N., \& Kadir, H. A. (2013). Information Technology Adoption in Malaysian SMEs. International Journal of Economic Perspectives, $7(4), 8 \mathrm{I}$.

Sila, I. (2013). Factors affecting the adoption of B2B e-commerce technologies. Electronic commerce research, I3(2), I99-236.

Skoko, H., Buerki, L., \& Ceric, A. (2007). Empirical evaluation of ICT adoption in Australian SMEs: Systemic approach. IEEE, Harbin, China, January, I5-I8.

Stockdale, R., Ahmed, A., \& Scheepers, H. (2012). Identifying Business Value From The Use Of Social Media: An Sme Perspective. Paper presented at the PACIS.

Taiminen, H. M., \& Karjaluoto, H. (2015). The usage of digital marketing channels in SMEs. Journal of small business and enterprise development, 22(4), 633-65I.

Tarutè, A., \& Gatautis, R. (20I4). ICT impact on SMEs performance. Procedia-social and behavioral sciences, IIO, I2I8$\mathrm{I} 225$.

Yu, Y., Wang, X., Zhong, R. Y., \& Huang, G. Q. (2016). E-commerce logistics in supply chain management: Practice perspective. Procedia CIRP, 52, I79-I85.

Yusuf, A. A. (2013). Impact of ICT on SMEs: case Rwanda. Thesis submitted to the department of International Business Management, Turku University of Applied Science, Finland.

Zaidan, E. (20I7). Analysis of ICT usage patterns, benefits and barriers in tourism SMEs in the Middle Eastern countries: The case of Dubai in UAE. Journal of Vacation Marketing, 23(3), 248-263.

\section{Copyrights}

Copyright for this article is retained by the author(s), with first publication rights granted to the journal. This is an open-access article distributed under the terms and conditions of the Creative Commons Attribution license (http://creativecommons.org/licenses/by/4.0/). 